IRSTI 06.56.31

UDC 364.3

https://doi.org/10.46914/1562-2959-2021-1-4-33-39

\author{
D.M. MUKHIYAYEVA, *1 \\ $\mathrm{PhD}$. \\ *e-mail: dinara_muhiyaeva@mail.ru \\ V.K. BARABOSHKIN, ${ }^{1}$ \\ PhD student. \\ e-mail:dj_dli@mail.ru \\ ZHIJIAN CUI, ${ }^{2}$ \\ professor of business administration. \\ e-mail: zhijianc@ustc.edu.cn \\ ${ }^{1}$ L.N. Gumilyov ENU Nur-Sultan, Kazakhstan \\ ${ }^{2}$ University of Science and Technology of China \\ China, Anhui Province
}

\title{
INNOVATIVE DEVELOPMENT MECHANISMS \\ OF HEALTH CARE AS A FOUNDATION \\ OF THE SOCIAL POLICY OF THE STATE
}

\begin{abstract}
The social policy of a modern state should be aimed at creating conditions that ensure a decent life for a person and their free development as an individual. The most important areas of social activity of the state should be labor protection and improvement of people's health, ensuring a guaranteed minimum wage, full employment, state support for large families, students, motherhood and childhood, disabled people and pensioners. The objectives of social policy are: increasing incomes and social protection of the population; optimization of social and labor relations; improving the health of citizens; protection of motherhood and childhood and state support of the family. These factors determine the relevance of studying and developing methods of financing healthcare. The article pays attention to the issues of social insurance, as it is an integral part of the general insurance system. However, social insurance has a number of significant features that are determined by the requirements of social protection of citizens. Together with the state budget, significant amounts of financial resources are accumulated in social insurance funds, directed to solving problems of socio-economic development, which is reflected in this article. In the practice of healthcare financing in Kazakhstan, certain negative trends have developed, leading to inefficiency in the use of allocated budget allocations, which are emphasized in the work. Based on the results of the study, the issues of creating a stable financial base for compulsory social health insurance in the Republic of Kazakhstan are systematized.
\end{abstract}

Key words: socio-economic development, healthcare, modernization, insurance, medical services, innovation, innovation mechanism.

\section{Literature review}

The strategy of socio-economic development of Kazakhstan until 2050 defines the directions of the third modernization of the country based on the implementation of five priorities, which are designed to ensure economic growth rates above the global average and on this basis, a steady promotion to the top 30 advanced countries of the world. One of the main priorities of the strategy is to improve the quality of human capital on the basis of an advanced health system, which is the main one in the process of implementing social policy. In the Address of the Head of state dated by January 31, 2017, "the Third modernization of Kazakhstan: global competitiveness", it is noted that the action of social policy should be aimed at creating productive employment opportunities for the population and at the availability of sustainable sources for the full life of each resident of the country [1].

The problems and ways to solve them in the field of innovation management are described in the works of Russian and foreign researchers: A.E. Abrameshin, Yu.P. Anisimov, V.P. Barancheev, I.A. Borisenko, V.P. Voronin, V.D. Zharikov, B.I. Gerasimov, Yu.V. Zhuravlev, C.B. Ildemenov, V.G. Medynsky, L.E. Mindeli, O.P. Molchanova, Yu.P. Morozov, T.I. Ovchinnikova, M. Porter, Yu.A. Salikov, J1.C. Slesareva,A.B. Surin, G.I. Tamoshina, B. Twiss, A.A. Trifilova, P.A. Fatkhutdinova, J.B. Shulgina, J.A. Schumpeter and other scientists. 
The works of V.M. Bautin, A.N. Borisov, I.P. Bogomolova, O.F. Bystrov, I.G.Dezhina, V.G. Zakshevsky, N.I. Ivanova, A.A. Ivashchenko, D.V. Kolobov, I.F. Narizhny, V.Yu. Padalkin, H.A. Pivovarov, V.Ya. are devoted to the issues of stimulating innovative activity of industries and complexes. Pozdnyakov, and other researchers.

\section{Introduction}

Material security and medical care provided by social insurance funds to disabled members of the society contribute to the restoration of workers' ability to work and their active life recovery in various sectors of the economy and fields of activity.

Mandatory social health insurance (MSHI) is a form of social protection of the population's interests in health protection in case of illness, injury, pregnancy and childbirth, disability and old age. Many developed countries have opted for an MSHI that allows funds to be reallocated from the less needy to the more needy. In Kazakhstan, a mixed model of health insurance has been introduced with the introduction of MSHI, taking into account the best world practices. This provides the following factors for the development of the medical industry and the quality of services provided:

- financial stability of healthcare;

- high level of quality and availability of medical services;

- a wide package of medical care.

\section{Methodology}

The methodological basis of the article research was the works of domestic and foreign scientists, experts and practitioners, presented in the modern economic literature, devoted to the problems of state regulation of innovative development of the healthcare sector.

The article is based on a comprehensive approach integrating the following research methods: comparative, structural, graphical, logical, statistical analysis.

\section{Results and discussion}

Table 1 presents a SWOT analysis of budget health programs, their advantages and disadvantages.

Table 1 - SWOT analysis of the budgetary programs of public health

\begin{tabular}{|l|l|}
\hline \multicolumn{1}{|c|}{ Strength: } & \multicolumn{1}{c|}{ Weakness: } \\
\hline - political support of the state and guarantee of & - low life expectancy and high overall mortality compared \\
fulfillment of social obligations; & to the average level of Organization for Economic \\
- overall successful implementation of the program- & Cooperation and Development (OECD) countries; \\
targeted method of financing medical programs; & - low level of GDP share for healthcare financing; \\
- stable epidemiological situation for most & - lack of mechanisms for joint and several liability for \\
infectious diseases with high immunization & health; \\
coverage; & - insufficient participation of the private sector in the \\
- experience in transferring modern medical & provision of guaranteed volume of free medical care; \\
technologies and highly specialized medical care; & - low level of corporate governance; \\
- encouraging and stimulating domestic drug & - low labor motivation of medical personnel due to the \\
manufacturers & low wages; \\
& - insufficient medication provision at the outpatient level \\
\hline
\end{tabular}

According to experts, the study of health financing issues should begin with the classification of health care, its main parts and elements. The World Health Organization (WHO) defines it as follows: "The health system is the aggregation of all organizations, institutions, and resources whose main goal is to improve health of the population" [2]. The Code of the Republic of Kazakhstan on citizens' health defines that the health system consists of state and non-state sectors [3]. Health care entities are mainly organizations that are under the jurisdiction of local executive bodies. Medical care and services are also provided by businesses engaged in private medical practice. A number of ministries and departments have their own medical facilities, and their expenses are included in the general budget of the relevant department. 
Medical organizations in the health care system of Kazakhstan have the following activities:

1) outpatient-polyclinic activities;

2) inpatient care;

3) emergency medical care and air ambulance;

4) disaster medicine;

5) activities in the field of service of blood;

6) activities in the field of forensic medicine and pathological anatomy;

7) pharmaceutical activities;

8) scientific and educational organizations of medicine.

Table 2 shows the main health indicators of the population in Kazakhstan during 2006, 20162019 years.

Table 2 - Main health indicators of the population of Kazakhstan

\begin{tabular}{|l|c|c|c|c|c|c|}
\hline & 2006 & 2016 & 2017 & 2018 & 2019 & 2020 \\
\hline Population, million people & 15,39 & 17,91 & 18,15 & 18,39 & 18,63 & 19,067 \\
\hline Birth rate, per 1,000 people & 19,71 & 22,52 & 21,64 & 21,77 & 21,73 & 22,4 \\
\hline Life expectancy, years & 66,15 & 72,41 & 72,95 & 73,15 & - & \\
\hline Maternal mortality, per 1,000 births & 45,60 & 15,70 & 14,80 & 13,91 & 13,4 & - \\
\hline Infant mortality, per 1,000 births & 13,91 & 8,59 & 7,93 & 8,03 & 8,37 & 7,8 \\
\hline Total mortality rate, per 1000 people. & 10,27 & 7,37 & 7,15 & 7,14 & 7,19 & 9,3 \\
\hline $\begin{array}{l}\text { Incidence of diseases of the circulatory system } \\
\text { (CSD), per 100,000 population }\end{array}$ & 9178 & 2413 & 2499 & 2502 & 2509 & 2811,9 \\
\hline Mortality from CSD, per 100 000 population & 533 & 179 & 189 & 194 & 199 & - \\
\hline $\begin{array}{l}\text { Incidence of malignant neoplasms (IMN), per } \\
\text { 100,000 population }\end{array}$ & 164 & 199 & 201 & 206 & 209 & 173,5 \\
\hline Mortality from IMN per 100 000 population & 115 & 88 & 93 & 98 & 95 & - \\
\hline
\end{tabular}

The provided data indicates positive changes in the country over the past twelve years. The population is growing, and the birth rate and life expectancy have increased. In some ways, Kazakhstan is approaching the developed countries of the world. Thus, the total mortality rate per 1000 people in 2006 was 10,27, and in $2019-7,19$, which, along with the birth rate, also has a positive impact on the duration indicator. At the same time, the rate of morbidity and mortality from malignant neoplasms is growing.

The health financing system provides information on expenditures by four main indicators: health services; health care providers; health financing schemes and the revenue of these financing schemes. Sources of healthcare funding include:

- state budget funds;

- assets of the mandatory social health insurance system;

- private or individual payment for medical services received by citizens, purchase of medicines;

- corporate medicine;

- charitable donation.

The goal of the health Finance system is to provide a clear and precise picture of key transactions (cash flows) and the structure of its individual elements. Health care providers are production units that receive money in exchange for performance or implementation, i.e., medical institutions and other entities in the health care system.

The system of healthcare financing covers a number of sources, the information base is:

- government expenditure (budget financing) - report on execution of the state budget, formed by the Ministry of Finance on a regular basis in terms of categories provided by the Unified budget classification;

- private expenditures of citizens-statistical bulletins of the Committee on Statistics of the Ministry of National Economy of the Republic of Kazakhstan, formed on a regular basis;

- expenditures from the mandatory social health insurance system - reports of the NAO "social health insurance Fund-FSMS", as well as reports of the NAO "State Corporation" Government for citizens"; 
- voluntary medical insurance-reports on insurance premiums and payments of insurance companies in Kazakhstan, formed by the National Bank of the Republic of Kazakhstan;

- external funding - provides funds for government loans and donor funds, and the government loans source of data is a report on the execution of the State Budget, formed by the Ministry of Finance.

Financing of entities that provide a guaranteed amount of free medical care (GAFMC) is carried out for:

1) for state medical institutions - under an individual funding plan;

2)for private healthcare entities-on a contractual basis with the administrators of budget programs and the Republic health service.

Medical care is provided in the following volumes:

1) basic-GAFMC, which is financed from the national and local budgets;

2) additional volume of medical care, including:

- medical care in the MSHI system provided in accordance with the Law of the Republic of Kazakhstan "on mandatory social health insurance";

- medical care under voluntary health insurance in accordance with the Law of RK "On insurance activities".

Guaranteed amount of free medical care (GAFMC) is provided to citizens of Kazakhstan at the expense of budget funds and includes preventive, diagnostic and therapeutic medical services with the greatest proven efficacy.

Financial resources of the healthcare system are directed to the following areas:

1) payment for the services of healthcare subjects within the framework of GAFMC;

2) material and technical equipment of healthcare organizations;

3 ) purchase of medicines, as well as medical devices and medical equipment;

4) elimination of epidemics cases;

5) training, advanced training and retraining of personnel.

6) medical science and basic research;

7) other expenses.

The budget is a complex multi-faceted phenomenon and must be explored from several angles.

First, in its economic essence, the budget expresses certain financial relations that have their own specifics. Secondly, the budget is a financial plan of the state, consisting of revenue and expenditure parts and having the force of law. Third, it is a fund of monetary funds.

The essence and significance of the budget are determined by economic relations in society. In a market economy, it is necessary to redistribute money and partially centralize it in the funds of the state in order to perform its functions. The funds necessary for the state to perform its functions are centralized at the disposal of the relevant authorities and management in the form of funds of monetary assets, the main and basic of these funds is the budget.

The main administrator of budget healthcare programs is the Ministry of Healthcare of the Republic of Kazakhstan. It should be noted that expenditures on healthcare in the structure of state budget expenditures (national and local budgets) on the social field occupy the third line after expenditures on social security and education.

The main share in the structure of budget funding of the medical industry is taken by "guaranteed free medical care" on state and local levels in the framework of the unified national health system (UNHS). The remaining expenses are mainly spent on medical infrastructure, scientific research, ensuring sanitary and epidemiological well-being, training and retraining of specialists, and so on. All budget funding for healthcare was indexed annually by the percentage of inflation.

A reasonably acceptable innovative mechanism is the principle of actuarial calculations for compulsory health insurance schemes based on a system of group equivalence between the incomes of socio-economic groups with insurance and the costs of these population groups. However, it should be borne in mind that there is a significant level of cross-subsidization among these groups, most often - subsidising working and self-employed citizens favouring persons with no income. Therefore, for simplicity, the equivalence between income and expenses for all insurance categories is assessed, followed by a targeted comparison of income and payments of individual socio-economic groups and a reduction in insurance premium rates, if necessary.

It will be possible to calculate the costs of providing medical care within the preferential package since it includes all costs associated with the existing health infrastructure. 
In the health care system of the Republic of Kazakhstan, relative to the period under review, there were systemic risks that can be classified as follows:

- the risk of increased consumption of medical services - due to demographic changes (birth rate growth, population aging) and the growth of certain types of diseases (cardiovascular diseases, oncology, etc.);

- the risk of increasing the cost of healthcare - intensive introduction of new expensive technologies (medicines, medical equipment and products);

- risk of insufficient state budget funds (deficit due to the economic situation) and lack of flexibility in the distribution of funds between regions and health levels;

- risk of inefficiency: failure to achieve the final results of budgetary health programs: low competence of the management system, underfunding of labor costs of human resources, inefficient use of allocations, corruption, etc.

There is a weak tariff policy and non-transparent distribution of funds in the country, due to the lack of a database on the actual costs of medical organizations for calculating tariffs, an inadequate cost structure of tariffs that does not take into account capital costs and depreciation charges, the cost of servicing medical and IT technologies, and the cost of financial services. The inadequacy of tariff regulation was compensated by strict volume control, which creates a pronounced imbalance between the levels of medical care. The existing internal problems and expected risks required a radical revision of the healthcare model.

In the Concept of introduction of mandatory social health insurance in the Republic of Kazakhstan until 2030 the following reasons and factors for reforming healthcare financing system are named:

1. Lack of solidarity between citizens and employers in healthcare field. Ensuring health protection is only the responsibility of the state, while the citizens themselves do not have a sufficient level of responsibility for their health (timely medical examinations, participation in recreational activities, refusal of bad habits, etc.).

2. Financial instability of the healthcare system. Despite the growth of public spending on health care, funding does not cover the growing needs of the population for medical care. The birth rate is increasing along with the aging of the population, and the number of chronic and non-communic diseases is also increasing;

3. The rapid pace of introduction of new innovative technologies in medicine continues, which, in turn, requires significant government expenditures;

4. Poor qualification of healthcare system management: a high share of inpatient care costs $51 \%$ in the structure of health financing (in the OECD countries, this is $34 \%$ ) due to the poor quality of medical services provided in primary healthcare;

5. Endless queues and unsatisfactory quality of services in medical organizations force people to go to private clinics. If wealthy citizens can afford high quality treatment and expensive medicines, the less billable categories of the population have a limited access to certain types of medical services.

6. The growth of complex and chronic diseases, coupled with the aging of the population leads to an increase in healthcare costs.

7. Numerous complaints of patients about the quality of medical care, low qualification of doctors, inefficient organization of hospitals and clinics create a general background of dissatisfaction with the existing healthcare system [7-9].

The introduction of compulsory health insurance is carried out in conjunction with the reform of the health care system in Kazakhstan [10, 11].

Thus, the current trend in the health care system (increase of non-communicable diseases, the carrying capacity of the system by the introduction of new technologies, the growth of birth rate, increase in elderly population) lead to increases in healthcare costs. In addition, there is a practice of inefficient and inappropriate use of allocated budget funds.

Thus, at present, the country has a new task to become one of the 30 most competitive countries in the world, which means a high level of quality of healthcare, with all countries of the world, it is necessary to solve the problems of global challenges related to the growth of life expectancy, chronic non-communicable diseases, which will inevitably lead to a further increase in the consumption and structure of medical services. 
In addition, it is necessary:

- to determine the actual costs of medical organisations as the primary providers of medical services for the costs of compulsory health insurance for outpatient care, inpatient care, outpatient drug provision and administrative costs;

- the compulsory health insurance system should also include expenses for the prevention and management of diseases, i.e. to direct the priorities to the development of primary health care in order to reduce the proportion of funding for inpatient care:

- the system of compulsory health insurance should be oriented towards increasing the efficiency of using the resources of the social health insurance fund.

Achieving this goal requires the system to quickly group its efforts to build a new, long-term health model based on the best examples of its own and international experience, which will ensure the availability and quality of medical services, while maintaining financial stability in any fluctuations of the world and domestic economy.

\section{REFERENCES}

1 Message of the President of the Republic of Kazakhstan dated by January 31, 2017 "The third modernization of Kazakhstan: global competitiveness". URL: https://www.akorda.kz.

2 World health organization: online questions and answers. URL: https: //www.mz.gov.kz.

3 Code of the Republic of Kazakhstan dated September 18, 2009. No. 193-IV. "On the health of the people and the health system". URL: https://online.zakon.kz.doc.

4 Internet resource Of the Committee on statistics of the Republic of Kazakhstan www.stat.gov.kz.

5 Code of the Republic of Kazakhstan dated September 18, 2009. No. 193-IV. "On the health of the people and the health system". URL: https://online.zakon.kz.doc

6 Resolution of the Government of the Republic of Kazakhstan dated April 21, 2014. No. 396. "On the Concept of introduction of mandatory social health insurance". URL: // https:www.akorda.kz

7 Saparova G.T. Compulsory medical insurance in the Republic of Kazakhstan // Bulletin of the Financial University, 2017, no. 2, pp. 145-154.

8 Shopabayeva A.R., Elshibekova K.M., Serikbayeva E.A. Issues of introduction of compulsory social health insurance in Kazakhstan // Bulletin of KazNMU. 2017, no. 3, pp. 365-368.

9 Duisenova T.K. Social security and social assistance in the Republic of Kazakhstan / Materials of the III International scientific and practical conference "From social protection to social progress", Astana, 2014, pp. 11-14.

10 Izimbergenova G.N., Gumarova G.Zh. The introduction of compulsory social health insurance in the Republic of Kazakhstan // Medical Journal, 2017, pp. 13-15.

Д.М. МУХИЯЕВА,*1

$\mathrm{PhD}$, ассоциированный профессор.

*e-mail: dinara_muhiyaeva@mail.ru

В.К. БАРАБОШКИН, ${ }^{1}$ докторант.

e-mail: dj_dli@mail.ru

ZHIJIAN CUI, ${ }^{2}$

профессор по бизнес-администрированию. e-mail: zhijianc@ustc.edu.cn

${ }^{1}$ Евразийский национальный университет им. Л.Н. Гумилева, Казахстан, г. Нур-Султан

${ }^{2}$ Университет науки и технологии Китая, Китай, Провинция Аньхой

\section{ИННОВАЦИОННЫЕ МЕХАНИЗМЫ РАЗВИТИЯ ЗДРАВООХРАНЕНИЯ КАК ОСНОВЫ СОЦИАЛЬНОЙ ПОЛИТИКИ ГОСУДАРСТВА}

Социальная политика современного государства должна быть направлена на создание условий, которые обеспечивают достойную жизнь человека и его свободное развитие как личности. Важнейшими направле- 
ниями социальной деятельности государства должны быть охрана труда и улучшение здоровья людей, обеспечение гарантированного минимума оплаты труда, полная занятость, государственная поддержка многодетных семей, учащихся, материнства и детства, инвалидов и пенсионеров. Задачами социальной политики являются: повышение доходов и социальной защищенности населения; оптимизация социально-трудовых отношений; улучшение здоровья граждан; охрана материнства и детства и государственная поддержка семьи. Этими факторами определяется актуальность изучения и разработки методов финансирования здравоохранения. В статье уделено внимание вопросам социального страхования, так как оно является составной частью общей системы страхования. Тем не менее социальное страхование имеет ряд существенных особенностей, которые определяются требованиями социальной защиты граждан. Вкупе с государственным бюджетом в фондах социального страхования аккумулируются значительные объемы финансовых ресурсов, направляемых на решение задач социально-экономического развития, что нашло отражение в данной статье. В практике финансирования здравоохранения в Казахстане сложились определенные негативные тенденции, приводящие к неэффективности использования выделенных бюджетных ассигнований, на которые акцентировано внимание в работе. По итогам проведенного исследования систематизированы вопросы создания устойчивой финансовой базы обязательного социального медицинского страхования в Республике Казахстан.

Ключевые слова: социально-экономическое развитие, здравоохранение, модернизация, страхование, медицинское обслуживание, инновация, инновационный механизм.

Д.М. МУХИЯЕВА,*1
PhD, қауымдастырылған професcop.
*e-mail: dinara_muhiyaeva@mail.ru

В.К. БАРАБОШКИН, ${ }^{1}$

докторант.

e-mail: dj_dli@mail.ru

ZHIJIAN CUI,

бизнес әкімшілік саласы бойынша профессор. e-mail: zhijianc@ustc.edu.cn

${ }^{1}$ Л.Н. Гумилев атындағы Еуразия ұлттық университеті, Қазақстан, Нұр-Сұлтан қ.

${ }^{2}$ Қытай ғылым және технология университет, Қытай, Аньхой Провинциясы

\section{ДЕНСАУЛЫҚ САҚТАУДЫ ДАМЫТУДЫҢ ИННОВАЦИЯЛЫҚ ТЕТІКТЕРІ МЕМЛЕКЕТТІҢ ӘЛЕУМЕТТІК САЯСАТЫНЫН НЕГІЗІ РЕТІНДЕ}

\section{Андатпа}

Қазіргі заманғы мемлекеттің әлеуметтік саясаты адамның лайықты өмірін және оның жеке тұлға ретінде еркін дамуын қамтамасыз ететін жағдайлар жасауға бағытталуға тиіс. Мемлекеттің әлеуметтік қызметінің аса маңызды бағыттары адамдардың еңбегін қорғау және денсаулығын жақсарту, еңбекке кепілдік берілген ең төменгі жалақыны қамтамасыз ету, толық жұмыспен қамту, көп балалы отбасыларды, оқушыларды, ана мен баланы, мүгедектер мен зейнеткерлерді мемлекеттік қолдау болуға тиіс. Әлеуметтік саясаттың міндеттері: халықтың табысы мен әлеуметтік қауіпсіздігін арттыру; әлеуметтік-еңбек қатынастарын оңтайландыру; азаматтардың денсаулығын жақсарту; ана мен баланы қорғау және отбасын мемлекеттік қолдау. Бұл факторлар денсаулық сақтауды қаржыландыру әдістерін зерттеу мен әзірлеудің өзектілігін анықтайды. Мақалада әлеуметтік сақтандыру мәселелеріне назар аударылады, өйткені ол жалпы сақтандыру жүйесінің ажырамас бөлігі болып табылады. Алайда, әлеуметтік сақтандырудың азаматтарды әлеуметтік қорғау талаптарымен анықталатын бірқатар маңызды белгілері бар. Мемлекеттік бюджетпен бірге әлеуметтік сақтандыру қорларында әлеуметтік-экономикалық даму міндеттерін шешуге бағытталған қаржы ресурстарының едәуір көлемі жинақталады, бұл осы мақалада көрініс тапты. Қазақстанда денсаулық сақтауды қаржыландыру тәжірибесінде бөлінген бюджет қаражатын пайдаланудың тиімсіздігіне алып келетін белгілі бір теріс үрдістер қалыптасты, жұмыста оларға баса назар аударылды. Жүргізілген зерттеу қорытындысы бойынша, Қазақстан Республикасында міндетті әлеуметтік медициналық сақтандырудың тұрақты қаржылық базасын құру мәселелері жүйеленді.

Тірек сөздер: әлеуметтік-экономикалық даму, денсаулық сақтау, жаңғырту, сақтандыру, медициналық қызмет көрсету, инновация, инновациялық тетік. 